Perwira Journal of Science and Engineering (PJSE)

E-ISSN : 2775-8486

Volume 1 Nomor 1

Februari 2021

\title{
ANALISIS KELAYAKAN FINANSIAL PADA USAHATANI PEPAYA CALINA / CALIFORNIA INDONESIA \\ (Carica papaya. L).
}

\author{
Dwi Putriana Nuramanah Kinding \\ Universitas Perwira Purbalingga \\ dwiputriana@unperba.ac.id
}

\begin{abstract}
ABSTRAK
Tujuan dari penelitian ini adalah untuk mengetahui: (1) kelayakan usahatani pepaya Calina (California Indonesia) yang dijalankan oleh seorang petani Pepaya California di Kota Banjar, (2) Payback Period (jangka waktu tercapainya net benefit menyamai investasi) pada usahatani pepaya Calina (California Indonesia) yang dijalankan oleh seorang petani pepaya Calina (California Indonesia) di Kota Banjar. Metode penelitian yang digunakan dalam penelitian ini adalah metode studi kasus. Penarikan sampel dalam penelitian ini adalah secara purposive sampling. Responden dipilih secara sengaja sebagai sampel dengan alas an hanya satu-satunya petani yang melakukan usahatani pepaya Calina (California Indonesia) pada lahan seluas 1,5 hektar dan hanya satu-satunya petani yang menerapkan teknik penanaman monokultur di Kota Banjar. Analisis yang digunakan dalam usahatani pepaya Calina (California Indonesia) ini adalah analsisi kelayakan finasial yaitu dengan menggunakan rumus NPV, IRR, Net B/C dan Payback Periods. Hasil analisis menunjukkan: Total Profit dan Net Benefit yang diperoleh Rp.134.776.400,00, Net Benfit Cost Ratio (Net B/C) sebesar 2,175, Net Present Value (NPV) sebesar Rp. 139,823,442.00, Internal Rate of Return (IRR) sebesar 17 persen (17\%). Dengan melihat beberapa kriteria kelayakan yang menunjukkan angka positif atau lebih besar dari nol dan IRR lebih besar dari bunga bank yang berlaku. Payback period yang diperoleh pada usaha tani pepaya yang diusahakan responden di Kota Banjar dicapai pada 2 tahun 2 bulan artinya modal yang diinvestasikan dapat dikembalikan setelah usahatani pepaya berjalan 2 tahun 2 bulan.
\end{abstract}

Kata Kunci: Usaha, Tani, Pepaya, California, Benefit

\section{PENDAHULUAN}

Buah-buahan merupakan salah satu produk hortikultura yang sangat potensial untuk memasuki perdagangan baik perdagangan di pasar domestik maupun Internasional. Hal ini dikarenakan produksi buah-buahan di Indonesia yang cukup besar dan juga buahbuahan Indonesia memiliki potensi pasar yang luas. Indonesia memiliki berbagai macam jenis buah-buahan yang dijadikan sebagai buah unggulan di Indonesia. Hal ini dikarenakan buah-buahan tersebut memberikan kontribusi yang cukup besar untuk diekspor ke luar negeri.

Komoditas pepaya pertumbuhan ekspor pada tahun 2009-2020 mengalami penurunan jumlah volume ekspor sebesar $-88,47$ persen dengan nilai ekspor menurun hingga $-91,4$ persen. Walaupun nilai ekspor pepaya terus mengalami penurunan tetapi permintaan untuk buah pepaya akan selalu ada. Permintaan tersebut berasal dari negara Jerman, Hongkong, Jepang, Malaysia, Singapura, Taiwan dan Amerika Serikat (Direktorat Jendral Hortikurtura, 2012). Permintaan pepaya yang terus ada dapat 
Perwira Journal of Science and Engineering (PJSE)

E-ISSN : 2775-8486

Volume 1 Nomor 1

Februari 2021

dijadikansebagai peluang bagi para petani untuk terus meningkatkan produksinya dan meningkatkan kualitas produk yang dihasilkan agar nilai ekspor untuk komoditas pepaya dapat terus meningkat.

Pepaya merupakan buah yang berasal dari Amerika Tropis, tetapi buah ini sangat dikenal oleh masyarakat Indonesia dari berbagai kalangan dan lapisan masyarakat, hal ini dikarenakan pepaya di Indonesia tersedia sepanjang tahun dan untuk melakukan budidaya pepaya tidak mengenal musim seperti komoditas buah durian dan mangga. Produksi pepaya di Indonesia terus ditingkatkan untuk memenuhi kebutuhan konsumsi pepaya di Indonesia. Peningkatan produksi tersebut dapat dilihat dari perkembangan peningkatan produksi pepaya dan luasan panen yang digunakan untuk melakukan budidaya papaya.

Usaha budidaya pepaya California memiliki nilai ekonomis yang tinggi karena harga pepaya California di pasaran jauh lebih tinggi bila dibandingkan dengan pepaya lokal. Pepaya California sangat diminati oleh kalangan menengah ke atas dan pada umumnya dijual di pasar swalayan atau supermarket. Berdasarkan hasil pengamatan yang dilakukan di Jogya Departement Store suatu pusat perbelanjaan terkemuka di Kota Banjar pada bulan Juli 2012, harga untuk pepaya California di supermarket mencapai Rp 7.990 per kg, sedangkan untuk pepaya lokal hanya berkisar Rp 4.000 per kg (Distan Banjar, 2012).

Permintaan pepaya banyak berdatangan dari pasar tradisional, rumah-rumah makan, swalayan dan supermarket. Permintaan juga banyak berdatangan dari pedagangpedagang buah yang bermunculan di berbagai tempat untuk menambah ragam dagangannya. Tingkat konsumsi buah pepaya termasuk tinggi bila dibandingkan dengan tingkat konsumsi buah-buahan lainnya. Hal ini merupakan peluang pasar dalam negeri untuk komoditas pepaya di Kota Banjar (Dinas Pertanian Kota Banjar, 2012).

Adanya permintaan dari supermarket yang berkelanjutan terhadap pepaya California, menjadi daya tarik tersendiri bagi para petani untuk melakukan kegiatan usahatani pepaya California tersebut. Hal ini terbukti dengan adanya petani yang mengalihkan usahanya untuk mencoba melakukan usahatani pepaya California dapat memberikan gambaran bahwa usahatani tersebut sangat digemari para petani saat ini. Hal ini disebabkan oleh usahatani tersebut dapat memberikan keuntungan yang cukup tinggi. Jumlah produksi pepaya California yang dihasilkan petani sangat dipengaruhi oleh luas lahan yang dimilikinya. Adanya luas lahan yang tidak seragam yang dimiliki setiap petani, akan menyebabkan jumlah produksi yang dihasilkan juga berbeda. Hal tersebut akan mempengaruhi tingkat penerimaan yang diperoleh petani tersebut.

Dengan adanya permasalahan-permasalahan yang dihadapi oleh para petani pepaya Calina (California Indonesia) di Kota Banjar seperti luas lahan, biaya tanam dan biaya pemeliharaan, maka perlu diadakannya suatu penelitian mengenai analisis kelayakan finansial pada usahatani pepaya Calina (California Indonesia) di Kota Banjar.

\section{KAJIAN PUSTAKA}

Sebagai buah segar, pepaya relatif disukai semua lapisan masyarakat karena cita rasanya yang enak, kaya vitamin A, B dan C yang sangat dibutuhkan oleh tubuh manusia. Semakin meningkatnya kesadaran masyarakat akan pentingnya gizi buah tersebut, dapat meningkatkan permintaan terhadap pepaya sehingga jumlah produksi pepaya juga harus ditingkatkan. Melakukan usaha budidaya pepaya California pada saat ini dapat meningkatkan kesejahteraan para petani, dikarenakan harga jual yang tinggi dan di dukung dengan permintaan pasar yang tinggi. Hal ini dapat dijadikan sebagai suatu 
Perwira Journal of Science and Engineering (PJSE)

E-ISSN : 2775-8486

Volume 1 Nomor 1

Februari 2021

peluang usaha bagi para petani untuk terus dapat memenuhi permintaan pasar akan pepaya California (Murbiyanto, 2008).

Setiap kegiatan suatu usaha tidak lepas dari tujuan utama yaitu untuk meningkatkan pendapatan pelaku usaha. Untuk mendapatkan pendapatan para pelaku usaha harus mengeluarkan sejumlah biaya tertentu. Tersedianya produksi dipengaruhi oleh berbagai faktor antara lain komoditi, luas lahan, tenaga kerja, modal, manajemen, iklim dan faktor sosial ekonomi produsen (Soekartawi, 2005). Faktor-faktor produksi tersebut yang kemudian akan dijadikan sebagian faktor yang diberikan agar fungsi produksi mampu menghasilkan dengan baik. Jumlah produksi pepaya California yang dihasilkan petani sangatdipengaruhi oleh luas lahan yang dimilikinya.

Untuk mengetahui kelayakan usahatani pepaya California ini harus diketahui dulu biaya proyek yang akan dikeluarkan. Biaya proyek adalah seluruh baya yang dikeluarkan proyek guna mendatangkan penghasilan (return) dimasa yang akan datang. Biaya proyek terdiri dari biaya investasi dan biaya operasional.

Biaya Investasi adalah seluruh biaya yang dikeluarkan dari mulai proyek tersebut mulai berjalan (beroperasi). Sedangkan biaya operasional adalah seluruh biaya yang dikeluarkan selama proses produski itu berlangsung.

Untuk mengetahui kelayakan usaha Maka digunakan analisis imbangan present value dari Net Benefit Cost Ratio (Net B/C), Net Present Value atau NPV (Nilai bersih sekarang) dan Internal Rate of Return (IRR). Net Benefit Cost Ratio (Net B/C) adalah perbandingan antara jumlah NPV positif dengan jumlah NPV negatif. Net Benefit Cost Ratio $(N e t B / C)$ ini menunjukkan gambaran bahwa berapa kali lipat Net Benefit Cost Ratio $(\mathrm{Net} B / \mathrm{C})$ kita peroleh dari cost yang kita keluarkan. Jika Net Benefit Cost Ratio $(\mathrm{Net} \mathrm{B} / \mathrm{C})$ $>1$ artinya positif berarti proyek menguntungkan, sebaliknya jika Net Benefit Cost Ratio $($ Net B/C) $<1$ artinya negatif berarti proyek merugi. Makin tingi nilai Net Benefit Cost Ratio $(\mathrm{Net} \mathrm{B} / \mathrm{C})$, maka usahatani pepaya California semakin menguntungkan (Sanusi, 2000).

Selanjutnya Sanusi (2000) menyatakan bahwa Net Benefit Cost Ratio (Net B/C) merupakan selisih antara benefit (manfaat) dibandingkan dengan cost (biaya). Jika NPV menunjukkan nilai positif atau lebih besar dari nol maka proyek tersebut menguntungkan dan layak untuk diusahakan. Untuk mengetahui persentae keuntungan dari suatu proyek tiap tahun digunakan Internal Rate of return (IRR). IRR ini merupakan alat ukur kemampuan proyek dalam mengembalikan bunga pinjaman.

Jenis penelitian yang dilakukan dalam penelitian ini adalah metode studi kasus. Daniel (2002) menyatakan bahwa:' metode studi kasus merupakan penelitian dimana populasi yang diteliti pada sifat tertentu yang tidak berlaku umum dan biasanya dibatasi oleh kasus, lokasi, tempat dan waktu tertentu atau terfokus pada sifat tertentu yang tidak berlaku umum.

Untuk menyamakan dan memperjelas pemahaman dalam penelitian ini, maka variabel-variabel yang diteliti, dioperasionalkan sebagai berikut:

1. Biaya adalah seluruh korbanan yang dipergunakan untuk menghasilkan pendapatan kotoir dan diukur dalam satuan rupiah (Rp).

2. Biaya investasi adalah pengeluaran-pengeluaran yang dilakukan oleh investor (petani) untuk pembelian barang-barang atau jasa yang dibutuhkan dalam rangka investasi atau dari mulai persiapan lahan sampai usahatani itu berjalan diukur dalam satuan rupiah (Rp).

Biaya investasi terdiri dari: 
Perwira Journal of Science and Engineering (PJSE)

E-ISSN : 2775-8486

Volume 1 Nomor 1

Februari 2021

a. Biaya sewa lahan, dinilai dalam satuan rupiah per hektar.

b. Pembelian bibit dihitung dalam satuan pohon dan dinyatakan dalam satuan rupiah per hektar.

c. Pembelian pupuk dasar (kandang) dihitung dalam satuan kilogram dan dinyatakan dalam satuan rupiah.

d. Pembelian peralatan, dinilai dalam satuan rupiah per hektar.

e. Biaya tenaga kerja untuk persiapan lahan, pemupukan dasar dan penanaman, dihitung dalam satuan Hari Orang Kerja (HOK) dan dinyatakan dalam satuan rupiah per hektar.

3. Biaya operasional dan pemeliharaan (Operating and Maintenance Cost) adalah biaya yang dikeluarkan secara rutin yang dikeluarkan selama umur proyek (selama proses produksi berlangsung) dinyatakan dalam satuan rupiah (Rp) yang meliputi:

a. Pajak lahan dinilai dalam satuan rupiah per hektar per tahun.

b. Pembelian pupuk dihitung dalam satuan kilogram dinyatakan dalam satuan rupiah per hektar per tahun.

c. Pembelian obat-obatan, dihitung dalam satuan kilogram dinyatakan dalam satuan rupiah per hektar per tahun.

d. Biaya tenga kerja untuk penyiangan, pemupukan, penyulaman, pemangkasan, pengendalian hama penyakit, panen dan pasca panen, dihitung dalam satuan Hari Orang Kerja (HOK) dan dinyatakan dalam satuan rupiah per hektar per tahun.

4. Produksi adalah proses yang dilaksanakan untuk menghasilkan produk.

5. Penerimaan yaitu jumlah produksi dikalikan dengan harga satuan produksi, dinilai dalam satuan rupiah per hektar per tahun.

6. Net Benefit Cost Ratio (Net B/C) perbandingan antara NPV positif dan NPV negatif.

7. Net Present Value (NPV) atau nilai bersih sekarang yaitu selisih antara Benefit (manfaat) dan cost (biaya) pada discount rate tertentu.

8. Internal Rate of Return (IRR) adalah discount rate yang membuat besarnya NPV proyek sama dengan nol dinyatakan dalam persen.

9. Payback period adalah jangka waktu tercapainya net benefit menyamai biaya investasi.

Asumsi yang digunakan dalam penelitian ini adalah:

a. Selama penelitian harga jual produk per satuan unit tetap

b. Selama penelitian harga faktor produksi tetap.

c. Hasil produksi habis terjual.

d. Usahatani pepaya California monokultur

e. Tingkat bunga bank yang berlaku selama penelitian sebesar $8 \%$ per tahun.

10. Penerimaan (benefit) usahatani (dalam rupiah) adalah merupakan nilai dari penjualan produksi total yang dihasilkan. Hasil penjualan diperoleh dari perkalian antara jumlah output yang dihasilkan dengan tingkat harga output.

Data yang dikumpulkan meliputi data primer dan data sekunder yang berkaitan dengan permasalahan yang akan dibahas dalam penelitian ini. Data primer diperoleh melalui wawancara langsung dengan petani, penyuluh pertanian dari Kantor Dinas Pertanian Kota Banjar yang disertai dengan panduan kuesioner yang dipersiapkan terlebih 
Perwira Journal of Science and Engineering (PJSE)

E-ISSN : 2775-8486

Volume 1 Nomor 1

Februari 2021

dahulu. Sedangkan data sekunder diperoleh dari lembaga atau instansi yang terkait yaitu Dinas Pertanian Kota Banjar, Badan Pusat Statistik, internet dan lembaga lainnya.

Pengambilan responden untuk petani dipilih secara purposive sampling yaitu penentuan sampel dengan tujuan tertentu yakni pemilihan satu atau kelompok yang didasarkan atas ciri-ciri atau sifat populasi yang sudah diketahui sebelumnya. Berdasarkan pengertian tersebut maka pada penelitian ini ditentukan sebanyak 1 orang petani pepaya California dengan luas lahan yang paling luas.

Pengolahan dan analisis data dilakukan secara kuantitatif dan kualitatif, untuk data kuantitatif pengolahan datanya dilakukan dengan menggunakan kalkulator dan komputer. Sebelum dilakukan pengolahan data terlebih dahulu dilakukan proses editing. Editing merupakan kegiatan untuk memperbaiki kualitas data mentah yang di dapat dari hasil wawancara dengan petani. Setelah data diedit dan diolah kemudian dilakukan analisis data. Sedangkan untuk data kualitatif, pengolahan datanya dilakukan secara deskriptif. Analisis data yang dilakukan pada penelitian ini adalah meliputi,

\section{Net B/C (Net Benefit Cost Ratio)}

Usahatani pepaya California dikatakan menguntungkan (profitable) apabila nilai Net $B / C>1$. Rumus yang digunakan untuk mengetahui $\mathrm{Net} B / C$ menurut Husnan dan Muhammad (2005) adalah:

$$
N e t B / C=\frac{\sum_{t=1}^{n} \frac{B t-C t}{(1+i)^{t}}}{\sum_{t=1}^{n} \frac{C t-B t}{(1+i)^{t}}}
$$

Keterangan:

$\mathrm{Bt}=$ penerimaan kotor pada tahun ke- $\mathrm{t}$

$\mathrm{Ct}=$ biaya kotor pada tahun ke-t

$\mathrm{n}=$ umur ekonomis proyek

$\mathrm{i}=$ tingkat suku bunga yang berlaku

\section{Net present Value (NPV)}

Net Present Value merupakan selisih antara penerimaan dengan biaya yang telah di-present value-kan. Dalam kriteria ini dikatakan bahwa proyek akan dipilih apabila nilai NPV lebih besar dari nol. Menurut Husnan dan Muhammad (2005), NPV adalah nilai sekarang dari arus manfaat yang ditimbulkan oleh penanaman investasi. Rumus NPV adalah:

$$
\mathrm{NPV}=\sum_{\mathrm{t}=0}^{\mathrm{n}} \frac{B t-C t}{(1+i)^{t}}
$$

Keterangan:

$\mathrm{Bt}=$ penerimaan usahatani pada tahun ke- $\mathrm{t}$

$\mathrm{Ct}=$ Cost (biaya usahatani pada tahun ke-t)

$\mathrm{n}=$ umur ekonomis proyek

$\mathrm{i}=$ tingkat suku bunga yang berlaku

Kriteria investasi berdasarkan NPV adalah:

NPV > 0, maka proyek menguntungkan dan dapat dilaksaknakan modal)

$\mathrm{NPV}=0$, maka proyek tidak untung tidak rugi (proyek dapat mengembalikan

NPV < 0, maka proyek ini merugikan karena hasil yang diperoleh lebih kecil dibanding biaya yang dikeluarkan, lebih baik tidak dilaksanakan. 
Perwira Journal of Science and Engineering (PJSE)

E-ISSN : 2775-8486

Volume 1 Nomor 1

Februari 2021

Dengan demikian, setelah arus manfaat bersih diperoleh dari hasil perhitungan maka kemudian nilai tersebut didiskon (dikalikan dengan discount faktor) selama kisaran waktu tiga tahun sehingga akan dihasilkan nilai sekarang atau present value dari arus manfaat bersih per tahunnya. Dari penjumlahan seluruh nilai sekarang atau present value dari arus manfaat bersih selama tiga tahun tersebut akan diperoleh nilai bersih sekarang atau net present value (NPV). Discount rate yang digunakan dalam perhitungan ini adalah sebesar 8 persen per tahun. Penentuan ini berdasarkan tingkat suku bunga Bank Indonesia.

\section{Internal Rate of Return (IRR)}

Kriteria yang menunjukkan bahwa suatu usaha layak dijalankan adalah jika nilai IRR lebih besar dari tingkat suku bunga yang berlaku pada saat usahatani tersebut diusahakan. Rumus untuk mencari IRR menurut Husnan dan Muhammad (2005) adalah:.

$$
I R R=i_{1}+\frac{N P V_{1}}{N P V_{1}-N P V_{2}}\left(i_{2}-i_{1}\right)
$$

Keterangan:

NPV1 = NPV yang bernilai positif

NPV2 = NPV yang bernilai negatif

$$
\begin{array}{ll}
\text { I1 } & =\text { tingkat suku bunga saat NPV bernilai positif } \\
\text { I2 } & =\text { tingkat suku bunga saat NPV bernilai negatif }
\end{array}
$$

Suatu proyek akan dipilih bila nilai IRR yang dihasilkan lebih tinggi daripada tingkat suku bunga yang berlaku (social discount rate) karena menunjukkan bahwa modal proyek akan lebih menguntungkan bila didepositokan di bank dibandingkan bila digunakan untuk menjalankan proyek.

\section{Analisis Payback Period}

Pay back period (PP) merupakan jangka waktu/periode yang diperlukan petani untuk membayar kembali semua biaya-biaya yang telah dikeluarkan untuk berinvestasi melalui usahatani pepaya California. Rumus untuk menentukan Payback Period menurut Husnan dan Muhammad (2005) adalah:

$$
P P=T_{p-1}+\frac{\sum_{i=1}^{n} I-\sum_{i=1}^{n} B_{i c p-1}}{B_{p}}
$$

Keterangan:

$\mathrm{T}_{\mathrm{p}-1} \quad=$ tahun sebelum terdapat PP

$\mathrm{I}_{\mathrm{i}} \quad=$ jumlah investasi yang telah di discount

$\mathrm{B}_{\text {icp-1 }}=$ jumlah pendapatanyang telah di discount sebelum PP

$\mathrm{B}_{\mathrm{p}} \quad=$ Jumlah pendapatantpada PP

\section{HASIL PENELITIAN DAN PEMBAHASAN}

Krieria kelayakan yang digunakan dalam analisis usahatani pepaya menggunakan empat criteria yaitu Total Profit, Net Beneft Cost Ratio (Net B/C) Net Prsenet Value (NPV) dan Internal Rate of Return (IRR), sedangkan untuk melihat kecepatan pengembalian modal digunakan Payback Period.

\section{Biaya Invetasi}

Biaya investasi merupakan seluruh biaya yang dikeluarkan sebelum usahatani pepaya itu berjalan, biaya investasi dalam suahatani pepaya yang dikeluarkan oleh Bapak Marta 
Perwira Journal of Science and Engineering (PJSE)

E-ISSN : 2775-8486

Volume 1 Nomor 1

Februari 2021

terdiri dari Sewa lahan, pembelian bibit pepaya, pembelian pupuk kandang, pembelian ajir, pembelian peralatan, dan biaya tenaga kerja. Total biaya investasi per hektar yang dikeluarkan responden sebesar Rp. 15.390.000,00. Perincian biaya investasi dapat dilihat pada Lampiran 1.

\section{Biaya Operasional}

Biaya operasional merupakan biaya rutin yang digunkan oleh responden dalam melakukan usahatani pepaya, biaya ini meliputi: Biaya pajak lahan, pembelian pupuk, pembelian obat-obatan, pembelian peralatan, dan biaya tenaga kerja. Total biaya operasional yang digunakan dalam usahatani pepaya per hektar sebesar Rp. $64,279,600.00$. Perincian biaya operasional usahatani pepaya yang dikeluarkan responden dalam umur proyek dapat dilihat pada Lampiran 2.

\section{Penerimaan (Benefit)}

Berdasarkan informasi yang diperoleh dari petani bahwa jumlah rata-rata hasil panen yang diperoleh petani pepaya adalah $297.500 \mathrm{Kg} / \mathrm{Ha}$. Adapun harga jual komoditas yang ditawarkan untuk produk yang dihasilkan oleh petani bervariasi tergantung dari grade yang dihasilkan, untuk pepaya dengan grade A (bentuk lonjong tidak terlalu besar) harga jualnya Rp $2.400,00 / \mathrm{Kg}$, sedangkan untuk pepaya grade B (bentuk bulat) harga jualnya $\mathrm{Rp} 1.200,00 / \mathrm{Kg}$, sedangkan untuk pepaya dengan grade $\mathrm{C}$ (bentuk rusak) harga jualnya $\mathrm{Rp} \mathrm{500,00/Kg}$. Apabila jumlah hasil panen tersebut dikalikan dengan harga jualnya maka akan diperoleh nilai produksi atau penerimaan usahatani. Adapun hasil perhitungannya dapat dilihat pada table berikut ini:

Tabel 1. Analisis Penerimaan Usahatani Pepaya di Kota Banjar Selama Tiga Tahun (Satu Kali Tanam) Per Hektar

\begin{tabular}{|l|r|r|}
\hline Uraian & Petani Pepaya $(\mathrm{Rp})$ & Persentase (\%) \\
\hline Penerimaan usahatani & & 60 \\
\hline Grade A & $152,064,000.00$ & 35 \\
\hline Grade B & $44,352,000.00$ & 5 \\
\hline Grade C & $2,640,000.00$ & $\mathbf{1 0 0 , 0 0}$ \\
\hline Total penerimaan & $\mathbf{1 9 9 , 0 5 6 , 0 0 0 . 0 0}$ & \\
\hline
\end{tabular}

Berdasarkan Tabel 1 di atas diketahui penerimaan total usahatani pepaya untuk petani adalah sebesar Rp 199.056.000, 00. Para petani pepaya umumnya menjual seluruh hasil panennya. Tingginya harga jual pepaya per kilogram yang diterima oleh petani dikarenakan kualitas pepaya yang dihasilkan, sehingga nsumen bersedia untuk membayar mahal produk tersebut. Selain itu tingginya harga jual tersebut ditetapkan oleh lembaga pemasaran (pengusaha mitra) agar dapat mengangkat pendapatan petani pepaya di Kota Banjar.

\section{4. $\quad$ Total Profit (Keuntungan Absolut)}

Total Profit merupakan selisih antara seluruh penerimaan (Total Revenue) dikurangi seluruh biaya (Total Cost). Total Profit yang juga merupakan Net Benefit (Sanusi, 2008) hasil penelitian menunjukan bahwa Net Benefit yang diperoleh petani responden selama umur tanam per hektar adalah sebesar Rp 199.056.000, 00, karena Total Profit menunjukkan angka positif, maka usahatani pepaya yang diusahakan responden di Kota Banjar layak dilaksanakan.

\section{Net Present Value (NPV)}


Perwira Journal of Science and Engineering (PJSE)

E-ISSN : 2775-8486

Volume 1 Nomor 1

Februari 2021

Net Present Value (NPV) atau nilai bersih sekarang merupakan selisih antara Benefit (Manfaat) dengan Cost (biaya) pada Discount Rate tertentu. Net Present Value (NPV) yang diperoleh selama umur proyek per hektar pada Discout Rate 12 persen, karena nilai Net Prsent Value (NPV) pada Discount rate 12 persen lebih besar dari nol atau positif, maka usahtani pepaya yang diusahakan petani di Kota Banjar layak diusahakan. Perincian perhitungan Net Present Value dapat dilihat pada tabel 2.

Tabel 2. Perhitungan NPV

\begin{tabular}{|l|l|r|l|r|}
\hline NO & Tahun & Pendapatan & df $(12 \%)$ & PV \\
\hline 1 & I & $12,061,200.00$ & 0,893 & $10,770,651.60$ \\
\hline 2 & II-III & $161,923,200.00$ & 0,797 & $129,052,790.40$ \\
\hline & & NPV & $139,823,442.00$ \\
\hline & & & & 2,175 \\
\hline \multicolumn{2}{|l|}{ B/C ratio }
\end{tabular}

\section{Net Benefit Cost Ratio (Net B/C)}

Net Benefit Cost Ratio (Net B/C) merupakan perbandingan antara NPV Positif dengan NPV negatif pada Discount Rate yang pertama (12\%). NPV positif dari usahatani pepaya responden adalah Rp.10.770.651,00, karena nilai Net Benefit Cost Ratio (Net B/C) lebih besar dari 1, maka usahatani pepaya yang diusahakan petani di Kota Banjar layak diusahakan.

\section{Internal Rate of Return (IRR)}

Internal Rate of Return (IRR) merupakan salah satu criteria penilaian proyek yang membuat besarnya NPV mendekati nilai nol. Internal Rate of Return (IRR) yang diperoleh dari usahatani pepaya responden adalah sebesar 17,31 persen, sehingga usahtani tersebut menguntungkan dan layak diusahakan, karena lebih besar dari bunga bank yang berlaku yaitu 12 persen.

\section{Payback Period}

Payback Period bukan merupakan criteria kelayakan namun Payback Period diartikan sebagai jangka waktu kembalinya invesati yang lebih dikeluarkan, melalui keuntungan yang diperoleh suatu proyek. Hal ini biasanya digunakan oleh pihak pemilik modal untuk mengkukur berapa tahun kemampuan proyek dapat mengembalikan pinjaman. Semakin cepat Payback Period, semakin baik untuk diusahakan. Jangka waktu tercapainya Payback Period pada usahatani pepaya responden 2 tahun 6 bulan, yang diperoleh dari penjumlahan Net Benefit tiap tahun (Net Benefit kumulatif) dibandingkan dengan investasi yang telah dikeluarkan.

\section{KESIMPULAN DAN IMPLIKASI}

Berdasarkan hasil dan pembahasan, maka dapat ditarik kesimpulan sebagai berikut :

1. Besarnya biaya yang dikeluarkan petani pepaya per hektar yang diusahakan reseponden selama umur proyek adalah : 1) Biaya investasi Rp.15.390.000,00, 2) Biaya operasional Rp.27.146.800,00, 3) Toal biaya Rp.64.279.600,00. Total 
Perwira Journal of Science and Engineering (PJSE)

E-ISSN : 2775-8486

Volume 1 Nomor 1

Februari 2021

Profit dan Net Benefit yang diperoleh Rp.134.776.400,00, Net Benfit Cost Ratio (Net B/C) sebesar 2,175, Net Present Value (NPV) sebesar Rp. 139,823,442.00, Internal Rate of Return (IRR) sebesar 17 persen (17\%). Dengan melihat beberapa kriteria kelayakan yang menunjukkan angka positif atau lebih besar dari nol dan IRR lebih besar dari bunga bank yang berlaku maka usahatani pepaya yang diusahakan petani di Kota Banjar layak untuk diusahakan.

2. Payback period yang diperoleh pada usaha tani pepaya yang diusahakan responden di Kota Banjar dicapai pada 2 tahun 2 bulan artinya modal yang diinvestasikan dapat dikembalikan setelah usahatani pepaya berjalan 2 tahun 2 bulan.

Berdasarkan kesimpulan, maka disarankan agar usahatani pepaya yang dilakukan oleh Bapak Marta diteruskan, karena usahatani yang dilaksanakannya dapat menghasilkan keuntungan atau layak. Untuk dapat meningkatkan keuntungan dari usahtani pepaya, sebaiknya dilakukan pemeliharaan yang lebih intensif lagi.

Perlu adanya upaya dari Dinas Pertanian untuk menginformasikan kepada petani untuk melakukan penanaman sesuai standar yang telah ditetapkan untuk budidaya pepaya sehingga dapat meningkatkan produktivitas yang pada akhirnya dapat meningkatkan kesejateraan petani itu sendiri. Selain itu untuk memperlancar petani dalam pengembangan sistem usahatani pepaya di Kota Banjar, maka sebaiknya sarana dan prasarana yang dibutuhkan oleh petani dapat dilengkapi. Contohnya saja saluran irigasi dan sarana transportasi yang belum memadai.

\section{DAFTAR PUSTAKA}

Anjayani dan Haryanto, 2009. Geografi untuk Kelas X SMA/MA Jakarta. Pusat Pembukuan, Depdiknas

Badan Pusat Statistik. 2011. Produk Domestik Bruto Menurut Sektor Usaha di Indonesia tahun 2011.Jakarta.

Dahl, DC dan Hammond, J. 1997. Market and Price Analysis The Agricultural Industries. Mc. Graw-Hill Inc. New York.

Departemen Pertanian. 2012. Perkembangan Produksi Beberapa Buah Unggulan Indonesia. Jakarta.

Direktorat Jenderal Hortikultura. 2011. Direktorat Tanaman Buah. Departemen Pertanian. VademekumPepaya (Carica Papaya).

2011. Survey Pertanian Produksi Tanaman Pangan dan Buah-buahan di Indonesia. Jakarta.

Ernawati. 1999. Analisis Pemasaran Buah Durian Simas dan Matahari. Kasus Pada Desa Rancamaya, Kecamatan Bogor selatan dan Desa Sukaraja, Kecamatan Sukaraja, Kabupaten Bogor. Skripsi Jurusan Ilmu-Ilmu social Ekonomi Pertanian.Fakultaspertanian.IPB. Bogor. 
Perwira Journal of Science and Engineering (PJSE)

E-ISSN : 2775-8486

Volume 1 Nomor 1

Februari 2021

Kadariah. 1986. Evaluasi Proyek. LembagaPenerbit FEUI. Jakarta

Hernanto, F. 1991. Ilmu Usahatani. Penerbit Penebar Swadaya. Jakarta.

Husnan S. Muhammad, 2008 Studi Kelayakan Proyek. Unit Penerbit dan Percetakan Yogyakarta

Kallie, M, B. 2002. Bertanam Pepaya. Penerbit Penebar Swadaya. Jakarta.

Kasmir, S.E.,MM. dan Jakfar, S.E.,MM. 2007. Studi Kelayakan Bisnis. Kencana Prenada Media Group. Jakarta.

Kottler, P. 2008. Manajemen Pemasaran. Edisi Milenium. Prehallindo. Jakarta.

Limbong, W, M. Dan P. Sitorus. 1987. Pengantar Tataniaga Pertanian. Bahan kuliah Jurusan Ilmu - Ilmu social Ekonomi Pertanian IPB. Bogor.

Mubyarto. 1986. Pengantar ekonomi Pertanian. Penerbit LP3ES. Jakarta.

Prestiani.2004. Analisis Usahatani dan Pemasaran Buah - Buahan Unggulan di Kabupaten serang .Skripsi Jurusan Ilmu - Ilmu Sosial Ekonomi Pertanian.Fakultas Pertanian.IPB. Bogor.

Rukmana, Rahmat. 1995. Pepaya, Budidaya dan Pasca Panen. Penerbit Kanisius. Yogyakarta.

Soekartawi, Soeharjo, Dillon, dan Hardaker. 1986. Ilmu Usahatani dan Penelitian Untuk Pengembangan Petani Kecil. Universitas Indonesia Press. Jakarta. 